\title{
IMPLICAÇÕES SOCIOAMBIENTAIS ENTRE CAMPONESES E O AGRONEGÓCIO DO DENDÊ NO NORDESTE PARAENSE
}

\author{
Rafael Benevides de Sousa ${ }^{1}$ \\ Cátia Oliveira Macedo ${ }^{2}$
}

\begin{abstract}
Resumo: Este artigo tem como objetivo discutir questões socioambientais impetradas em comunidades rurais, pressionadas pela produção da palma de dendê no nordeste paraense, em particular, nos municípios de Acará, Bujaru e Concórdia do Pará. Os dados de campo revelaram que a entrada do dendê nessa região da Amazônia pressionou os territórios campesinos, agravando problemas relacionados à água e à floresta. Destacaram-se especialmente os impactos relacionados aos igarapés, espaços de sociabilidade e rememoração das ancestralidades, agora impróprios para a realização da vida em decorrência dos poluentes químicos que fluem dos campos de dendê e alcançam os igarapés. Outros fatores concorreram para isso: o desmatamento, o consequente avanço de bichos peçonhentos sobre as unidades domésticas e os problemas relacionados a mobilidade em decorrência das péssimas condições das vias de acesso aos territórios campesinos cercados pelo dendê. Como metodologia de pesquisa, utilizamos a pesquisa de campo, a captação de dados qualitativos, com a técnica de entrevista sobre a história de vida.
\end{abstract}

Palavras-chave: Camponeses; Agronegócio do Dendê; Implicações Socioambientais; Nordeste Paraense.

\section{SOCIAL AND ENVIRONMENTAL OUTCOMES BETWEEN PEASANTS AND DENDÊ AGRIBUSINESS IN THE PARAENSE NORTHEAST}

\begin{abstract}
This article aims to discuss social environmental issues raised by rural communities, pressed up by the dendê palm production in Paraense northeast, particularly in towns as Acará, Buraju and Concórdia do Pará. The field data show that the establishing of dendê in this region compressed the peasant territories, worsening problems related to the access to water and to the forest. In this text, it is especially stressed the impacts on small streams, sociality spaces and the recollection of ancestral practices, now impossible to be accessed due to the flowing of chemical pollution in dendê fields in the reach of water streams. Other circumstances contributed to this: the deforestation, the subsequent advance of venomous animals onto dwellings and the burdens concerning mobility, due to the lousy condition of roads that go through peasant territories surrounded by dendê. As

\footnotetext{
${ }^{1}$ Docente Adjunto do Curso de Geografia do Instituto de Estudos do Trópico Úmido da Universidade Federal do Sul e Sudeste do Pará (UNIFESSPA). benevidessousa@gmail.com

2 Docente Adjunta do Departamento de Ciências Sociais e Educação da Universidade do Estado do Pará (UEPA). ccatiammacedo@gmail.com

Estudos Geográficos, Rio Claro, 17(1): 256-278, jan./jun. $2019 \quad$ (ISSN 1678-698X) http://www.periodicos.rc.biblioteca.unesp.br/index.php/estgeo
} 
Implicações socioambientais...

research methodology, we employed fieldwork, the gathering of qualitative data and interviews on life history.

Keywords: Peasants; Dendê Agribusiness; Social Environmental Outcomes; Paraense Northeast.

\section{INTRODUÇÃO}

Este artigo tem como objetivo discutir questões socioambientais impetradas em comunidades rurais pressionadas pela produção da palma de dendê no nordeste paraense, em particular nos municípios de Acará, Bujaru e Concórdia do Pará. Os dados de campo revelaram que a entrada do dendê nessa região da Amazônia pressionou os territórios campesinos, agravando, especialmente, problemas relacionados à água e à floresta. Destacou-se especialmente os impactos relacionados aos igarapés, espaços de sociabilidade e rememoração das ancestralidades, agora impróprios para a realização da vida em decorrência dos poluentes químicos que fluem dos campos de dendê e alcançam os igarapés, 0 desmatamento e o consequente avanço de bichos peçonhentos sobre as unidades domésticas e os problemas relacionados a mobilidade em decorrência das péssimas condições das vias de acesso aos territórios campesinos cercados pelo dendê. Como metodologia de pesquisa, utilizamos a pesquisa de campo, a captação de dados qualitativos, com a técnica de entrevista sobre a história de vida.

A literatura existente acerca da expansão do dendê no Pará apresenta perspectivas distintas a respeito da eficiência ou ineficiência da cultura da palma, enquanto um componente social de desenvolvimento regional. Os adeptos da lógica desenvolvimentista destacam as possibilidades de ascensão social das famílias camponesas. Entre esses trabalhos, destacamos os desenvolvidos pelos pesquisadores e professores da Embrapa e do Núcleo de Ciências Agrárias da Universidade Federal do Pará. Uma segunda interpretação tem sido apresentada, tomando como referência a perspectiva de território usado por Milton Santos, em que Nahum e Santos $(2014 ; 2017)$ traçam a terminalidade camponesa frente a este empreendimento capitalista, ou mesmo, reforçam a perspectiva da metamorfose de camponeses em agricultores familiares. E, por fim, Macedo e Sousa (2016), na tentativa da construção de uma interpretação sobre a espacialização do dendê na Amazônia, entendem que o capitalismo não destrói totalmente as formas de vida e de produção não capitalistas, mas, contraditoriamente, os camponeses têm conseguido reproduzir-se em paralelo à agricultura capitalista da palma de óleo.

O surto da produção do dendê nesse início do século XXI justifica-se pela possibilidade de produzir biodiesel menos poluente a partir da oleaginosa, alcançando, assim, as metas estabelecidas pelos acordos do clima. Contudo, observa-se que essa cultura, enquanto uma produção capitalista, tem quebrado parte dos ciclos itinerantes da agricultura camponesa regional, anulando o sistema de pousio e exaurindo o uso do solo com a monocultura da palma e seu pacote de veneno.

Assentado numa suposta perspectiva de sustentabilidade, que viabilizaria a recuperação de áreas degradadas, sequestro de carbono, inserção da agricultura camponesa na cadeia produtiva e na produção de um combustível mais limpo, 0 cultivo do dendê vem se expandindo (BECKER, 2010). Contudo, estudos demostram que a expansão da oleaginosa tem sido tão degradante quanto outras formas de

Estudos Geográficos, Rio Claro, 17(1): 256-278, jan./jun. 2019 (ISSN 1678-698X) http://www.periodicos.rc.biblioteca.unesp.br/index.php/estgeo 
apropriação do capital, não cumprindo, portanto, a meta de sustentabilidade (HOMMA, VIEIRA, 2012; MACEDO, SOUSA, 2016; GOMES et. al., 2016; SOUSA, 2018).

Em meio a esse processo, as comunidades camponesas têm visto seus territórios serem cercados pela palma e, consequentemente, pressionadas por uma agricultura estranha ao seu modo de vida e produção. Desse modo, o tema campesinato continua na agenda do dia, seja para traçar sua tragédia social, via o processo de descampesinização (NAHUM, BASTOS, 2015; 2017), seja para desvendar os elementos que permeiam a sua recriação no bojo do desenvolvimento desigual e combinado do capital (SOUSA, 2018; MACEDO, SOUSA, 2016).

Trazemos nesse trabalho dados empíricos referentes aos problemas socioambientais motivados pela expansão da monocultura do dendê no nordeste paraense. Indiscutivelmente, a chegada do monocultivo da palma gerou um campo de tensão, evidenciando, a partir de então, uma disputa territorial caracterizada pelos conflitos em torno dos recursos da natureza - terra, água, floresta, entre outros bens comuns.

Como metodologia, utilizamos a pesquisa de campo, a coleta de dados qualitativos, com a técnica de entrevista sobre a história de vida, para a qual a oralidade dos sujeitos sociais são fonte imprescindível para a compreensão da transformação ocorrida nessa parte da Amazônia, após a expansão do agronegócio do dendê.

O artigo está estruturado em uma única sessão centrada na discussão das tensões e dos conflitos socioambientais gerados nesse campo em disputa. De forma mais específica, focaliza-se na interferência desse empreendimento nos igarapés/rios, na destruição da cobertura vegetal, na já precária rede de mobilidade e infraestrutura disponíveis nesses territórios. Em certa medida, o ataque à água e a floresta norteiam o foco da ação da empresa. Como resposta a esses ataques, os camponeses vêm empreendendo a luta pelo território.

\section{UM CAMPO ENTRE CAMPONESES E O AGRONEGÓCIO DO DENDÊ}

Nós, Tembé, quilombolas e ribeirinhos de Tomé-Açu, Acará /PA, tentamos por diversas vezes entrar em acordo com o grande projeto criminoso que se chama BIO-PALMA que se instalou há quatro anos no entorno da nossa área, desmatando as cabeceiras dos nossos rios e igarapés para o cultivo do DENDÊ, onde na última terça-feira 08/12/15 foi encontrado um igarapé secando com muitos peixes morrendo, tudo isso está contribuindo para perda de tradição cultural e ambiental para atual e futura geração.

Às autoridades Federal, Estadual e Municipal: vejam com mais cuidado e com mais atenção a vida humana que é mais importante; onde estão os direitos humanos? Onde estão os direitos à vida, à flora, à fauna e aos recursos hídricos? Respeitem as pessoas mais humildes.

BIO-PALMA, junto com policiais e funcionários, está fazendo ataques em áreas ribeirinhas e quilombolas, fazendo humilhação, usando de torturas, carregando seus materiais de trabalho, queimando casas

Estudos Geográficos, Rio Claro, 17(1): 256-278, jan./jun. 2019 (ISSN 1678-698X) http://www.periodicos.rc.biblioteca.unesp.br/index.php/estgeo 
entre outros. Revoltados, comunidades indígenas, quilombolas e ribeirinhos tomaram uma decisão de ir para a luta contra esta maldita empresa que trouxe consigo venenos, produtos químicos como agrotóxico e muitos outros prejuízos às comunidades tradicionais, ameaçando até de morte índios, quilombolas e ribeirinhos. Queremos dizer que não vamos recuar, quando prendem 10 dos nossos, têm, mas 200 paralutar.

Em torno de nossos territórios tem grandes plantações de DENDÊ, onde está o dinheiro para fazer minimizar o impacto que esse maldito projeto está causando para as comunidades que estão à mercê do abandono como na Saúde, Educação estrada, transporte e saneamento para as áreas onde os igarapés estão poluídos por agrotóxicos? Se não pagar, a BIO-PALMA vai ter que ir embora de perto de nosso povo, para não ficar atentando contra a nossa vida, como aconteceu na última quarta-feira que prenderam 12 quilombolas, só vamos parar quando deixarem nossas terras e nosso povo em paz.

Vão plantar DENDÊ lá pro exterior que é de onde vem os recursos financiando esses grandes empreendimentos.

Cartas do povo indígena Tembé, quilombolas e ribeirinhos. Denunciamos para ONU, aqui no Brasil os nossos direitos estão sendo violados, estamos morrendo, isso é em todo território Nacional brasileiro, prova disso é a PEC215 que transfere do executivo para o congresso a competência da demarcação de terras indígenas, o que já e um direito conquistado. Terra indígena turé mariquita, quilombolas e ribeirinhos. (Carta de Repúdio dos Tembé, Quilombolas e Ribeirinhos de Tomé-Açu, Acará-PA, contra a Biopalma) ${ }^{3}$.

A carta dos Tembés, quilombolas e ribeirinhos dos municípios de Tomé-açu e Acará sinaliza para a tensão e o conflito socioambiental que emergem com a expansão do agronegócio do dendê no nordeste paraense. Esse, por sua vez, além de engendrar uma disputa territorial sobre a terra, tem orquestrado um intenso desmatamento, interferindo no ecossistema das comunidades rurais ao entorno desse empreendimento capitalista.

A tensão territorial que se dilata entre os interstícios da agricultura capitalista do dendê e a agricultura camponesa colocam em questão o uso sustentável dos recursos da natureza. A palma do dendê tem uma vida de 30 anos, sendo conduzida em plantios racionalizados em áreas contínuas de monocultura, com forte uso de agrotóxicos. Já agricultura camponesa, conforme observado em campo, conduz a uma produção itinerante de uso do solo (entre um ou dois anos), à agricultura diversificada (mandioca, milho, arroz, feijão, verduras e leguminosas) e à utilização de adubos orgânicos. Após a colheita, inicia o sistema de pousio que possibilita a recuperação de nutrientes da terra para o uso futuro. $\mathrm{Na}$ agricultura camponesa ainda se destaca a extensão produtiva do sítio familiar, com pomares de frutas regionais, cultivo da pimenta-do-reino, a criação de animais domésticos, e outros.

\footnotetext{
3 Disponível em 28 de julho de 2017: https://acervo.racismoambiental.net.br/2015/12/13/carta-de-repudio-dos-tembequilombolas-e-ribeirinhos-de-tome-acu-acara-contra-a-biopalma/

Estudos Geográficos, Rio Claro, 17(1): 256-278, jan./jun. 2019 (ISSN 1678-698X) http://www.periodicos.rc.biblioteca.unesp.br/index.php/estgeo
} 
Notamos que a diferença entre essas agriculturas (capitalista e camponesa) não se restringe apenas às relações produtivas e econômicas, mas também à forma diferenciada de apropriação dos recursos da natureza, o que fica bem evidente na conversa com os camponeses e exemplificado no excerto que segue:

A gente ainda tem parte de mata no nosso terreno, mata fechada. Porque a gente não trabalha com tudo né, porque não adianta a gente devora tudo né, acabar com tudo, acabar com a mata e com tudo, fica difícil até a chuva pra gente. Aí nós não derruba, a gente só trabalha assim, na capoeira que já era, quando comprei já era assim, capoeira fina (A. C., Comunidade Conceição do Guajará, Bujaru, 16 de maio de 2016).

Observamos na fala de A. C., da comunidade de Conceição do Guajará/Bujaru, que o uso da terra pela família camponesa nos remete à pesagem trabalho - consumo delineado por Chayanov (2014). Nesse caso, a família utiliza os recursos naturais de acordo com a necessidade doméstica e da composição familiar, desmatando apenas o que será utilizado para garantir o bem-estar. Contudo, quanto maior o número de familiares trabalhando para sobreviver numa mesma propriedade, maior será a utilização da terra e o encurtamento do tempo de pousio do solo.

Por outro lado, um grande número de famílias trabalhando numa mesma propriedade pode comprometer a reprodução social dos núcleos domésticos, mediante a intensa utilização da terra, o que ocasiona o empobrecimento do solo e, consequentemente, baixa produtividade.

Porém, esse uso intenso da propriedade acontece pela necessidade das famílias que têm na mesma terra de herança, os mecanismos de garantir a vida. Assim, delineamos que as implicações ambientais da agricultura camponesa é fruto de um problema social, originário da desigual distribuição da terra na AmazôniaBrasil. Além disso, o difícil acesso à terra, incorre na concentração de inúmeras famílias numa mesma propriedade, morando e trabalhando no lote. Isso intensifica o sistema de corte e queima, levando as famílias camponesas a utilizarem de forma mais acintosa os espaços agricultáveis das propriedades.

Já na agricultura capitalista, a propriedade é dividida entre a área produtiva e outra de reserva ambiental obrigatória pelo Código Florestal Brasileiro. Tal divisão, segue as linhas cronometradas para a utilização ao máximo possível para a reprodução de capital. Nesse caso, os danos ambientais não ocorrem pela necessidade de sobrevivência dos proprietários da terra, mas pela possibilidade de gerar e acumular mais capital.

Diante desse antagonismo, emergem tensões e conflitos ambientais entre as empresas agrárias capitalistas e as populações camponesas e indígenas que constituem formas diferenciadas de exploração da natureza, conforme necessidades e projetos específicos. Além dessa diferença, a pesquisa aponta que as empresas do dendê têm criado problemas socioambientais nas comunidades camponesasquilombolas e indígenas no nordeste paraense, como o relatado na carta dos Tembé, quilombolas e ribeirinhos.

A pesquisa nos indicou que os danos ambientais produzidos nos campos do dendê transcendem o limite territorial da empresa, comprometendo o modo de vida das populações camponesas. São muitos os campos de tensões e atritos, porém a questão em torno da água ganha destaque, como podemos observar na fala de A. C., da comunidade de Conceição do Guajará/Bujaru: "o problema aqui é quando Estudos Geográficos, Rio Claro, 17(1): 256-278, jan./jun. 2019 (ISSN 1678-698X) http://www.periodicos.rc.biblioteca.unesp.br/index.php/estgeo 
chega o verão, a água fica difícil pra gente. Porque muita gente diz que a gente vive aqui é cercado né, é dendê pra um lado, é dendê pro outro e, eles trabalham com muito veneno, né. Aí a gente não sabe se a água é contaminada né ou não" (16 de maio de 2016). Nessa fala, observamos o receio do uso da água por essa família devido ao grande teor de agrotóxico que é lançado nos campos do dendê e que, consequentemente, ultrapassa o meio ecológico da empresa, gerando implicações graves ao bem comum das comunidades rurais próximas.

O maior problema ambiental aqui é o desmatamento, principalmente o provocado na época da Biovale [Biopalma] que foi um desmatamento geral né. $\mathrm{E}$ outro problema ambiental também causado pela Biovale é a contaminação da água dos igarapés, mudou muito, a água fica todo tempo quando chove, ela muda de cor devido as estradas, que a água desce pelas estradas que vem dos campos de dendê, joga tudo nos igarapés né. A Biovale [Biopalma], ela desmatou praticamente só o que tinha aqui nesse meio, acho que a metade do Acará, metade de Concórdia, metade de Bujaru, tudo desmatado. Hoje não se vê quase campo aberto, porque do plantio de dendê. Mas aí que tá o problema, plantio de dendê é todo tempo com veneno pra agrotóxico, com adubo né, isso aí vem a chuva e leva tudo pra dentro dos igarapés (C. C., Comunidade Mariquita, Acará, 10 de setembro de 2016).

É trazendo destruição. Trouxe um benefício? Trouxe, que foi emprego pra várias pessoas, mas por outra parte, trouxe uma devastação de terra grande né. Trouxe também, fez as pessoas vender as terras e depois ficar trabalhando na própria empresa de dendê. Aconteceu tudo isso daí. A gente tá vendo que os igarapés se acabando, acredito que foi culpa de uma parcela aí do dendê que causou isso. A gente vê umas estradas completamente abandonadas, destruída, tem uma parcela do pessoal do dendê? É sim. O igarapé mudou muito totalmente (G. N., Comunidade Mariquita, Acará, 20 de agosto de 2016).

O desmatamento na área de expansão do dendê aparece de forma recorrente nas falas recolhidas em campo, contrariando a tese de que a oleaginosa teria sido implantada como um mecanismo de recuperação de áreas degradadas. Com isso, a pesquisa aponta para o fato de que o empreendimento da palma de óleo na Amazônia vem contribuindo para a vulnerabilidade dos territórios das comunidades camponesas, seja, pela tentativa de inviabilizar a terra/água, como meio de reprodução da vida, seja pela violação dos bens comuns, seja pela violência física - assaltos e roubos.

Aqui mudou sim, pra uma situação pior, porque pelo menos o nosso igarapé que era uma água maravilhosa, hoje em dia você passa, você vê a situação, água barrenta, contaminada, não presta pra beber e antes prestava pra beber, era água cristalina. $E$ fora os insetos que apareceu aí, acabou com a natureza (P. M., comunidade Conceição do Guajará, Bujaru, 17 de maio de 2016).

Eu acho que continuou mais pior, porque pelo menos antes a gente podia tirar água do igarapé. Hoje nós não pode tirar água do igarapé, a gente fica com dificuldade, o meu poço deu problema e aí tô com

Estudos Geográficos, Rio Claro, 17(1): 256-278, jan./jun. 2019 (ISSN 1678-698X) http://www.periodicos.rc.biblioteca.unesp.br/index.php/estgeo 
dificuldade de água porque não posso pegar no igarapé. Porque a agua é contaminada, porque eles colocam veneno por tudo aí. Aí cai tudo no igarapé. Eles adubam com veneno esse dendê aí, aí chove, aí veio pro canal né. Só melhorou pra aqueles que pegaram emprego que melhorou (P. C., Comunidade Mariquita, Acará, 4 de setembro de 2016).

Muita coisa mudou, por exemplo, mudou em questão de trabalho, benefício pra muitas pessoas, tá entendendo. Mas mudou também em questão de coisa ruim pra gente. Primeiro, a começar pelos bichinhos, muito bicho que não tinha, maruim, carapanã, mosca entendeu? Antes a gente podia baixar qualquer panela de carne, de peixe que as moscas não parecia, mas agora você só pode comer de noite de tanta mosca. Segundo, os nossos igarapé se acabou, o Igarapé Cravo, que era a coisa mais linda do mundo, e agora acabou. Porque o dendê, o pessoal do dendê eles desmataram a cabeça do igarapé, desmataram, destruíram. Eu não sei quando vieram fazer um restauramento aí, mas vieram, veio o professor Manuel, veio a professora Luzia, veio muita gente lá do Cravo, veio fazer porque desmataram tudo, eles acabaram com tudo. Aonde você ainda vê um pouquinho de água é porque acumulou um lago, mas só no inverno. Mas água, água mesmo é dali do Nando que forma um pouco de água e no verão ele fica só aquela imundice. Olha, tá com três anos que esse igarapé secou, fica só aquele buraco, acabou (I. S., Comunidade, Castanhalzinho, Concórdia do Pará, 22 de janeiro de 2017).

Pro agricultor aqui piorou, por prova eu não sei se você já observou, mas coisa que nós não tinha aqui, a gente tinha, mas era muito pouco, hoje nós tem com fartura esses bichinho que tá lhe perturbando, isso é proveniente do dendê. Outra questão é a poluição dos igarapés que afetou muito. Antes a gente usava água do igarapé pra tomar banho, pra lavar roupa, pra beber e pra tudo, pro consumo em geral. E depois que abriu essa, esse serviço aí, dessa firma, os igarapés ficaram inútil pro consumo (J. S., Comunidade Conceição do Guajará, Bujaru, 12 de maio de 2016).

Á água do igarapé a gente só usa pra banho, a gente não toma. A gente agora tem água encanada. O Governo Federal mandou a verba e a prefeitura executou. Mas isso foi com muita briga nossa lá, porque a água ficou poluída através dos agrotóxico jogado aí pela empresa né. Agora diminuíram mais, eles pararam de jogar porque foram multados, teve gente que teve problema de saúde, saia cheio de alergia quando saia do igarapé. Agora parou mais. Mas ninguém sabe como é que tá a água do poço aí né, porque levaram uma amostra pra fazer análise, mas até agora ninguém trouxe o resultado pra gente saber se a água tá boa (C. A., Comunidade Arapiranga, Concórdia do Pará, 18 de julho de 2017).

Para além da pressão sobre a terra, o dendê também se constitui a partir da pressão sobre os recursos hídricos, que na Amazônia tem a denominação indígena de igarapé (ou rio). O uso dos igarapés pelos camponeses faz parte da vida cotidiana, além de ser o principal meio de mobilidade para quem vive em seus

Estudos Geográficos, Rio Claro, 17(1): 256-278, jan./jun. 2019 (ISSN 1678-698X) http://www.periodicos.rc.biblioteca.unesp.br/index.php/estgeo 
arredores. Atualmente, os igarapés também se destacam como espaço de lazer, de produção, de serviços domésticos e de balneários recreativos.

Com o processo de lixiviação no período chuvoso (inverno amazônico), pressupõem-se que o agrotóxico dos campos da oleaginosa é lançado nos igarapés, impedindo o uso pleno desse bem comum pelas famílias camponesas. Além disso, muitas das vicinais abertas para o escoamento da produção aterraram nascentes e cursos d'água, interferindo de forma negativa no volume dos igarapés a jusante ao polo de cultivo da empresa.

A cabeceira desse igarapé ficou dentro desse terreno da Biovale [Biopalma], onde tem dendê. $E$ teve uma época que os peixe começaram a morrer até uns dias aí. Ninguém sabia o porque esses peixe tava morrendo, a água tava boa e os peixe morrendo, foi muito peixe. Ninguém botava veneno, porque se a pessoa joga veneno a gente sabe que o peixe morre. A água ficou grossa, porque a água quando seca não fica assim. Aquilo ficou grossa, parece que jogaram um troço que a água engrossou, ficou feia. Aí o pessoal da Sema vieram aí. Aí nós fizemo uma reclamação e agora melhorou (M. R., Comunidade Castanhalzinho, Concórdia do Pará, 28 de janeiro de 2017).

Depois que plantaram dendê, parece que secou os igarapés, as vezes jogam veneno no tempo de inverno e escorre pros igarapés. Ali é uma cabeceira de igarapé, logo quando cheguei por aqui tinha nascente, tudo por aí, tinha peixe tamuatá que era tudo cheio isso aqui. Agora tá tudo seco. Ano passado vinha do serviço, ia na casa do vizinho porque aqui não tinha nem água no poço. Parece que o dendê chupa muito a água (O. B., Comunidade Castanhalzinho, Concórdia do Pará, 17 de janeiro de 2017).

Uma das preocupações locais é referente aos igarapés que margeiam as comunidades rurais, que passaram por significativas transformações com a introdução do cultivo da palma. O igarapé Cravo, citado nas entrevistas, é um importante curso d'água, permeando várias localidades até a sua Foz no rio Bujaru. Entre as comunidades destacam-se: Castanhalzinho, $\mathrm{Km} \mathrm{35}$, Cravo, Sagrada Família, São Judas, Bom sucesso e a Foz do Cravo.

A empresa, ela se instituiu, se consolidou em meados de 2007, 2008 e 2009, né, derrubando e plantando dendê. E em 2010, 2011, nós começamos haver uma diferença no nível do nosso igarapé. Não só no nível, que começou a secar bastante, coisa que nunca havia acontecido, secar né, e não só isso, as pessoas começaram a sentir algumas doenças de pele né, coceira e entre outras, derivado da grande quantidade de adubo né, aplicado as margens do igarapé e que descia e o povo ia tomar banho e acabava-se contraindo doenças de pele. Em 2012 e 2013 o assoreamento do igarapé ficou visível né, em meses de verão amazônico, que é julho, agosto, setembro e outubro, você passava já em 2014 pelo igarapé andando, e não molhava nem a canela como o povo fala. Então começou a notabilizar o assoreamento drástico do igarapé e obviamente que o povo começou a perceber que era influência da implantação da empresa né, dos despejos de veneno, do desmatamento provocado pela empresa. Por que o pequeno produtor também desmata né,

Estudos Geográficos, Rio Claro, 17(1): 256-278, jan./jun. 2019 (ISSN 1678-698X) http://www.periodicos.rc.biblioteca.unesp.br/index.php/estgeo 
também polui, só que em pequena quantidade, a porcentagem é mínima se for comparado os danos que uma empresa como essa causa o igarapé por exemplo. Então, hoje, no atual ano de 2018, a gente vai onde era a cabeceira do igarapé Cravo e a gente vê algo absurdo, seco né, seco completamente. Em fevereiro de 2017, nós nos constituímos em um mutirão e fomos limpar o igarapé, desde a cabeceira. $E$ de onde nasce o igarapé Cravo pra cá, nós temos praticamente dois quilômetros completamente seco, de trilha. Antes era o igarapé, lindo, que os antigos falam que era muito bonito, e a gente recorre dos nossos antigos pra ver como é que era, que não tem foto, não tem vídeo, não tem nada, e o povo diz que era algo muito bonito mesmo, e hoje é trilha, onde era igarapé, hoje é trilha. Então, é realmente um absurdo, e você vê os igarapés, agora não que tá no inverno amazônico né, as chuva, então eles estão razoavelmente cheios, mas quando chegar no nosso verão amazônico, ele vai secar que dá tristeza de olhar, você consegue atravessar sem molhar a canela como aqui dizem. Então, esses são os danos que a gente percebe e que é culpa sem dúvida da ação do homem e, em especial da ação da empresa instalada aqui, Biopalma ou Biovale, não sei bem como é a denominação dela, mas o povo atribui a ela, os danos que ela causou no nosso igarapé, assoreamento né, e o povo que acaba se padecendo, porque o povo precisa desse igarapé né, pra tomar banho, fazer lavagem de roupa, de louça, pra colocar a mandioca, que também prejudica o igarapé, mas não se compara aos danos da empresa. Então, as pessoas que foram prejudicadas pela ação empresarial do capitalismo selvagem, é realmente os menos favorecidos, é o povo que precisa desse igarapé, que não é só a comunidade do Cravo né, prejudicou a comunidade do Castanhazinho, que precisa. Prejudicou a comunidade do 40, que é o Velho Expedido, prejudicou a comunidade do Km 37, do Km 35 que é Nossa Senhora do Perpétuo Socorro, a comunidade do Cravo que é Nossa Senhora das Graças, até a comunidade do São Judas, que é Bujaru é prejudicada também pela ação dessa empresa. Então são esses os danos da ação negativa dessa empresa e não há preocupação em reparar esses danos né, (M. P., comunidade do Cravo, Concórdia do Pará, 2 de abril de 2018)

Nos depoimentos recolhidos, a exemplo do acima, o igarapé Cravo começou a perder volume de água após a instalação do Polo Concórdia, da Biopalma. Em alguns pontos desse importante curso d'água, não há mais água, ficando totalmente seco durante o verão amazônico. Isso, por sua vez, de acordo com os relatos, não ocorria antes da chegada do dendê nessa região. Essa fala sinaliza, ainda, a importância desse igarapé para um conjunto de comunidades rurais, destacando-se como um bem comum das famílias que fazem uso desse recurso. Mais do que um recurso, o igarapé constitui-se nessas comunidades como parte integrante da vida camponesa local e de suas ancestralidades, que tinham a partir do igarapé a convivência comunitária.

De acordo com informações registradas em campo, a nascente do igarapé Cravo foi aterrada pela empresa Biopalma, despertando entre as famílias dessas comunidades preocupação com relação ao futuro do igarapé que, como observado nas entrevistas anteriores, estava sem vida.

Estudos Geográficos, Rio Claro, 17(1): 256-278, jan./jun. 2019 (ISSN 1678-698X) http://www.periodicos.rc.biblioteca.unesp.br/index.php/estgeo 


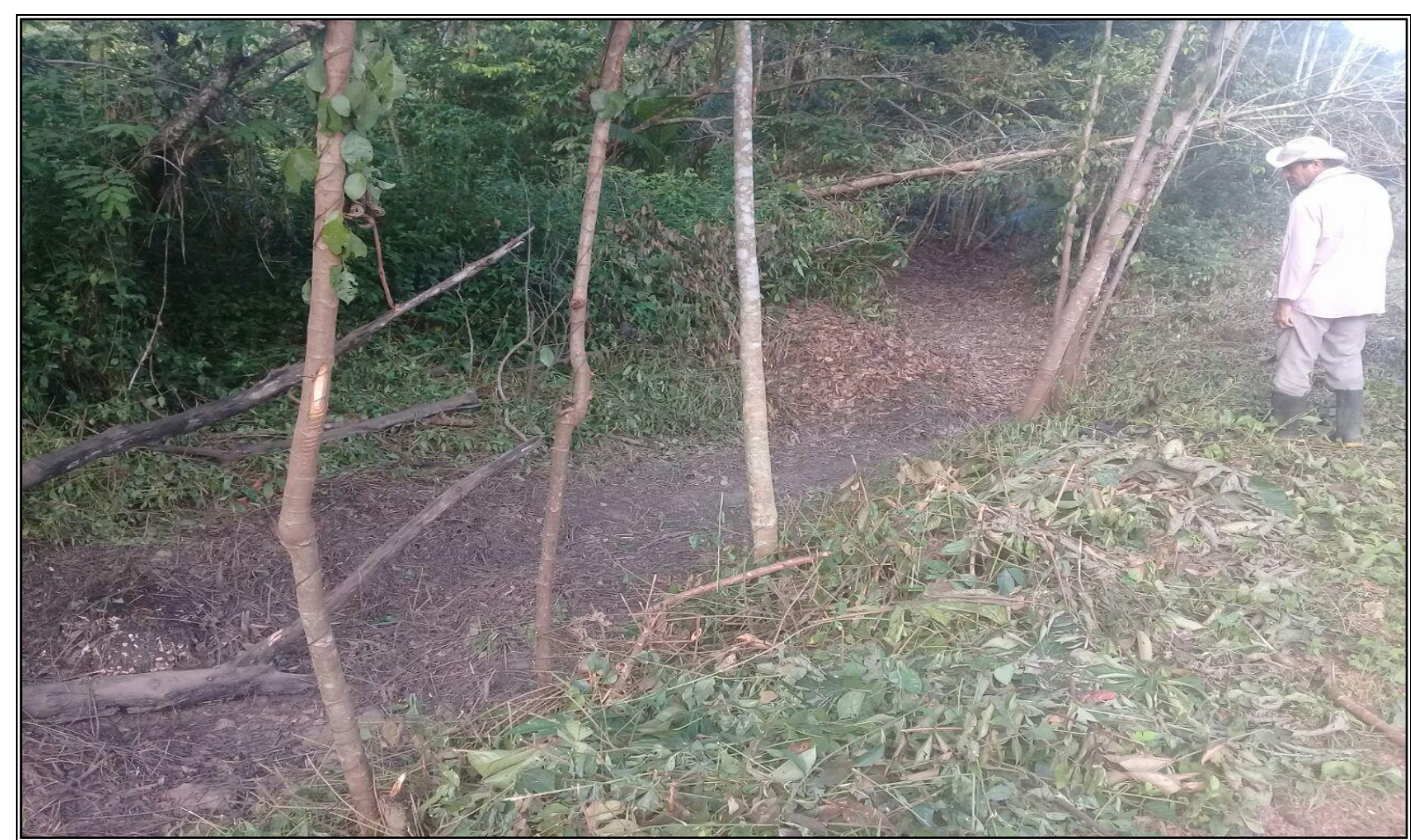

Fotografia 01 - Parte do igarapé Cravo que estava seco, em 2017.

Fonte: Pinheiro, 2017.

$\mathrm{Na}$ fotografia 01 , visualizamos o caminho que se formou onde antes correspondia ao tributário principal do igarapé Cravo. Soubemos em campo que, em 2017, o igarapé esteve totalmente seco. A sua nascente está localizada nas bordas do território da Biopalma, colocando a empresa na linha de frente e artífice dessa destruição ambiental, segundo dados das entrevistas.

Os igarapés da região são imprescindíveis para a produção da farinha de mandioca, em função do método de amolecimento do tubérculo nas águas dos igarapés. Estando o recurso hídrico contaminado, poderia afetar a produção e, consequentemente, a reprodução social da família. Outro ponto que podemos destacar é o fato de que alguns núcleos domésticos ainda utilizam água de poços amazônicos, e sem o filtro natural do lençol freático, essas águas podem causar problemas à saúde. Na fotografia a seguir, observaremos a cor da água do igarapé Cravo.

Estudos Geográficos, Rio Claro, 17(1): 256-278, jan./jun. $2019 \quad$ (ISSN 1678-698X) http://www.periodicos.rc.biblioteca.unesp.br/index.php/estgeo 


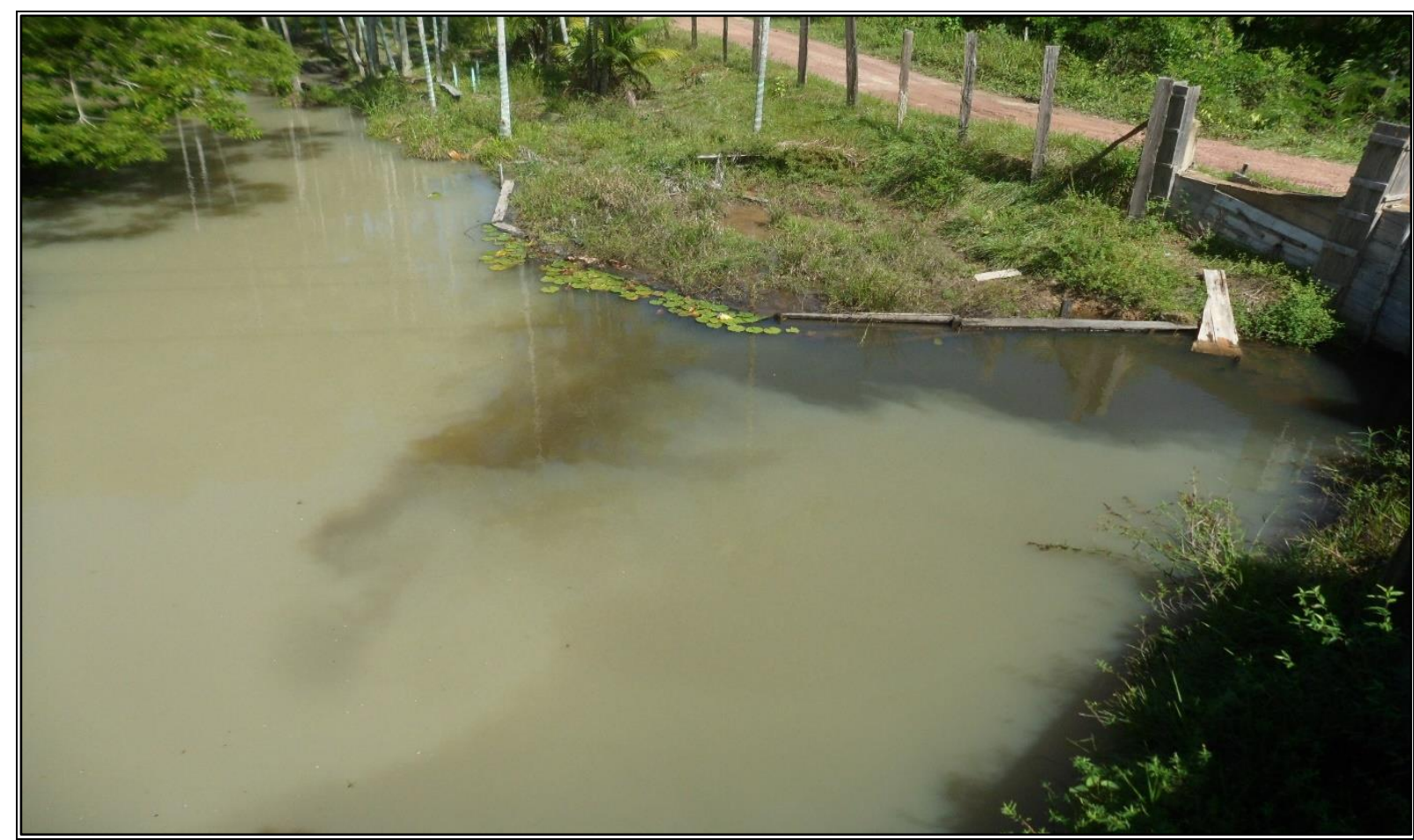

Fotografia 02 - Encontro dos igarapés Cravo e Galho Grande.

Fonte: Diário de campo, 2017.

Sobre o igarapé do Galho Grande (fotografia 02), soubemos em campo:

Esse lá [igarapé] é o Galho Grande que vem de Bujaru, pra lá não tem plantio de dendê, só tem fazenda, agricultura. Aí quando chega alí na ponte, o Cravo [igarapé] vem e aí eles se cruzam, a água preta e a água vermelha. Dá pra perceber a diferença. O Cravo ficou assim depois do dendê, ficou feio a água (M. S., Comunidade do $\mathrm{Km} \mathrm{35,}$ Concórdia do Pará, 15 de abril de 2017).

A entrevistada explica a diferença da cor das águas dos igarapés Cravo e Galho Grande, visualizados na fotografia 02, determinada pela trajetória feita pelos igarapés, o Cravo, pressionado pelos campos do dendê, e o Galho Grande, banhando os campos da agricultura camponesa.

Percorrendo essas comunidades, percebemos que os impactos e danos ambientais gerados pelo agronegócio do dendê extrapolam os limites de seu território. A poluição dos igarapés, estes vistos como um componente natural que transcende os limites territoriais da empresa tem afetado a vida camponesa, criando não apenas um problema ambiental, mas também social, ao passo que as famílias usam a água dos igarapés para afazeres diversos.

Desse modo, intuímos que o agronegócio do dendê não se faz sustentável, como afirmados nos projetos do Estado e de empresas capitalistas. Pelo contrário, trata-se, na prática, de atividades predatórias oriundas das relações engendradas pelo capitalismo neoliberal, para garantir a produção de alimento e de agrocombustível. Isso tem interferido no ecossistema e nas comunidades que fazem uso comum da natureza, que repartem a água, a terra, a floresta e o ar, bens que 0 capital insiste em privatizar.

Estudos Geográficos, Rio Claro, 17(1): 256-278, jan./jun. 2019 (ISSN 1678-698X) http://www.periodicos.rc.biblioteca.unesp.br/index.php/estgeo 
O problema ambiental também se constitui num limite ao agrocombustível. Embora exista o argumento de que se trata de energia "verde e limpa", porque emite menos de gases poluentes na atmosfera, o processo de produção é sujo, pois está assentado na monocultura que usa toneladas de agrotóxicos, fertilizantes, isso sem considerar as implicações das plantas transgênicas para o cultivo de soja destinada à fabricação de biodiesel (FABRINI, 2010, p. 73-74).

Fabrini (2010) é enfático ao afirmar que a expansão dos agrocombustíveis é acompanhada por um sistema produtivo agressivo à natureza, utilizando-se de produtos químicos que, ao serem lançados no ecossistema, criam um desequilíbrio ambiental, afetando todas as formas de vida em seu entorno.

Em diálogo com a perspectiva de Fabrini (2010), McMichael (2016) também tece uma crítica aos agrocombustíveis.

No caso dos agrocombustíveis, não são apenas um "crime contra a humanidade" ao tomar o lugar das culturas alimentares, de acordo com o ex-relator de direitos humanos da ONU, Jean Ziegler, mas também degradam o meio ambiente. Em suma, as culturas destinadas ao combustível ameaçam a reprodução social (ecologias de produção e humana) e, embora engordem as carteiras de investimento (em especial, com volumosos subsídios), ameaçam a sustentabilidade planetária e humana. [...]. O melhor exemplo disso é que os agrocombustíveis aumentam as emissões de carbono, não solucionam a crise energética e ameaçam as terras comunitárias, pradarias e florestas existentes - das quais uma grande parcela (e, em última instância, a totalidade) da humanidade depende e onde uma substancial porção de alimentos é produzida (MCMICHAEL, 2016, p. 179-180).

As explanações de Fabrini (2010) e McMichael (2016) aproximam-se do que é observado pelo avanço da palma do dendê no nordeste paraense, fruto das políticas direcionadas à produção dos agrocombustíveis. Nas comunidades pesquisadas, notamos que as bases produtivas da oleaginosa são danosas à natureza, gerando um desequilíbrio no ambiente onde as famílias camponesas vivem por gerações.

Uma das interferências no meio ecológico desses camponeses foi registrado na comunidade de Conceição do Guajará. O represamento do igarapé Guajará afetou a utilização desse recurso natural pelas famílias da localidade.

Estudos Geográficos, Rio Claro, 17(1): 256-278, jan./jun. $2019 \quad$ (ISSN 1678-698X) http://www.periodicos.rc.biblioteca.unesp.br/index.php/estgeo 


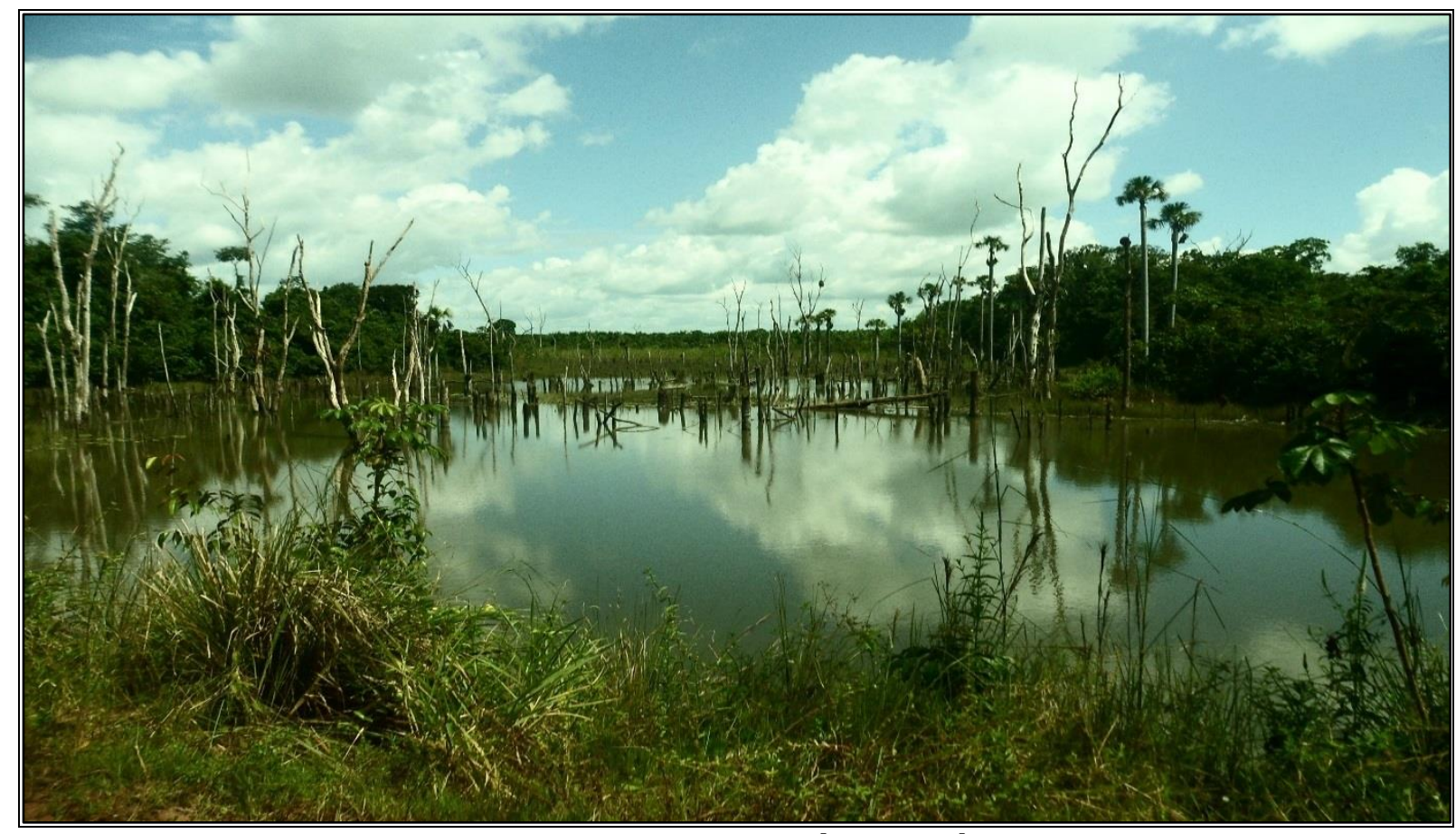

Fotografia 03 - Lago do represamento do igarapé Guajará.

Fonte: Diário de campo, 2016.

Na fotografia 03, observamos o lago que se formou após construção da barragem no igarapé Guajará para a construção de uma estrada de acesso aos campos do dendê. Como se pode visualizar, a formação do lago acompanhou a morte da vegetação, mudando o volume d'água e, consequentemente, afetando as famílias que fazem o uso dessa água.

Nós achemo ruim, mas só que fomo acha ruim depois. Ninguém nunca pensou porque a gente nunca tinha visto que fosse acontecer do jeito que aconteceu. Porque eles estavam fechando aí, fecharam no verão, na época do verão e pronto não aconteceu nada, não sujou a água e nada, e só fecharam lá. E no inverno que a água cresceu, a agua foi crescendo e depois que chegou o inverno aí o mato morreu tudo, água tomou conta do mato. O cara sentia a catinga da água de distância assim, aí que a água foi apodrecer. Tá com seis anos, depois de quase um ano que foi sentir o problema. Aí não tinha mais jeito. Só, a gente tem outro igarapé acolá, onde é meu terreno, tem a casa de farinha pra lá, é um outro igarapé que vai aí pra dentro. Aí um dia nós tava lá, quando nós vimo o igarapé começou a secar. Aí o compadre Zé, o Jipe, foi lá, que eles têm uma área que vai embora beirando o nosso terreno. Aí foi, eles estavam tapando o igarapé pra estrada, aí nós peguemo embarguemo. Mandamo eles olharem como tava ficando o nosso porto lá. Aí eles vieram, o trabalhador disse, olha eu vou avisar o chefe pra ele vim aí com vocês, aí fizermo uma reunião lá no Pedrinho com eles, na boca da noite, aí eles vieram e aí ele mandou abri e colocou tubo. Aí voltou ao normal. Mas só que esse outro aí, quando nós fomo abrir o olho, já era (J C, Comunidade Conceição do Guajará, Bujaru, 13 de maio de 2016).

As inquietações de J. C. nos oferecem elementos para entender os movimentos de resistências contra a interferência da empresa aos bens comuns das comunidades rurais. Notamos que a articulação dos camponeses para reverter 0 Estudos Geográficos, Rio Claro, 17(1): 256-278, jan./jun. 2019 (ISSN 1678-698X) http://www.periodicos.rc.biblioteca.unesp.br/index.php/estgeo 
soterramento do igarapé foi feita por meio das relações de vizinhança, que se mobilizaram para acionar a empresa responsabilizando-a pelo problema ambiental.

Vislumbra-se a comunidade, como instrumento de mobilização política, na qual as famílias camponesas se organizam em defesa do território e do bem comum, engendrando uma luta coletiva para assegurar os recursos indispensáveis à manutenção da vida. O mesmo não ocorreu com o represamento do igarapé Guajará, que teve o caminho d'água cortado pelos interesses produtivos da Biopalma. Desse modo, entendemos que a conformação territorial das propriedades capitalistas artificializa o ecossistema de acordo com as necessidades de ampliação e acumulação de capital, destruindo os recursos comuns e de direitos da população camponesa e indígena.

Fluímos, assim, para o entendimento de que a disputa territorial entre o agronegócio do dendê e as comunidades camponesas não se dá apenas pela terra, mas também por outros recursos naturais que fazem parte do ecossistema no qual a terra capitalizada está inserida. Em 2010, a CPT registrou 87 conflitos pela água, envolvendo quase 200 mil pessoas (CANUTO, MALVEZZI, 2011).

Dos conflitos de 2010, 54\% estiveram relacionados ao uso e preservação da água, 31\% a barragens e $25,5 \%$ açudes e $9 \%$ à apropriação particular, 10,39\% aconteceram nas seguintes situações: destruição e/ou poluição, pesca predatória, divergências na comunidade, impedimento de acesso à água, expropriação ou ameaça de expropriação, não reassentamento ou falta de projeto de assentamento ou reassentamento inadequado, não cumprimento de procedimentos legais (CANUTO, MALVEZZI, 2011, p. 18).

Em 2016, o número de conflitos pela água praticamente dobrou em relação aos dados de 2010, sendo registrados 172 casos pela CPT, o maior índice desde 2002, quando se iniciou a contabilizar esses tipos de conflitos (COSME, 2016).

Dentre os sujeitos sociais que sofreram algum tipo de violência nos Conflitos pela Água têm-se os ribeirinhos com $37,21 \%$ do total, seguido pelos pescadores com 18,02\%, ficando os pequenos proprietários e os indígenas, com $9,3 \%$ e $8,72 \%$, respectivamente. Juntos esses quatro grupos sociais sofreram violência em 126 (73,26\%) dos 172 Conflitos pela Água no ano de 2016. Os atingidos por barragem $(6,98 \%)$, os posseiros e os quilombolas $(5,81 \%$ cada), os assentados $(3,49 \%)$ e outros $(4,65 \%)$ (geraizeiros, camponeses de fecho de pasto, camponeses de fundo de pasto, lideranças, marisqueiros, trabalhadores rurais e vazanteiros), não menos importante, sofreram algum tipo de violência nos 46 (26,74\%) conflitos restantes (COSME, 2016, p. 130).

A partir desses dados, observamos que a ação capitalista no campo está na base dos conflitos agrários, havendo uma disputa pelo bem comum (terra, água, floresta, ar) que faz parte dos vínculos da população camponesa e indígena ao território de vida.

Essa ditadura do capital, que transforma o bem comum em recurso explorando-os e levando-os à exaustão, tem sido debatida por intelectuais latino-

Estudos Geográficos, Rio Claro, 17(1): 256-278, jan./jun. $2019 \quad$ (ISSN 1678-698X) http://www.periodicos.rc.biblioteca.unesp.br/index.php/estgeo 
americanos e brasileiros ${ }^{4}$. Esses autores, por meio da perspectiva da reprimarização da economia ou do neoextrativismo, expõem as formas perversas com que as instituições capitalistas articuladas aos estados nacionais capitalizam os recursos da natureza.

A acumulação capitalista requer crescentemente escalas mais amplas de produção, novos espaços sociais, mas físicos também (concentração do uso dos recursos hídricos nas mãos de grandes hidrelétricas, grandes projetos de irrigação, grandes projetos mineradores, frentes especulativas que incorporam grandes regiões de terras nas fronteiras etc.). Ao fazer-se essa concentração, desenvolve-se também, através do padrão tecnológico dominante, um processo de hegemonização dos conteúdos biofísicos do território: a disseminação de monoculturas, a substituição de diversidade por espécies dominantes e, concomitantemente, a substituição da diversidade social pela relação social capitalista dominante. (ACSELRAD, 2008, p. 6).

E continua,

A expansão própria a essa acumulação extensiva, termina resultando na destruição de formas sociais não-capitalistas de apropriação do meio ambiente e também na desestabilização dos sistemas ecológicos no espaço ocupado. Começa-se a desmatar margens de rios, os corpos d'água são assoreados e secam, constrói-se uma sequência enorme de barragens - tudo em nome da acumulação, apresentando-se como pretexto a necessidade de responder a determinadas demandas do progressos e do bem-estar, em nome de uma concepção industrialista de progresso, desestruturam-se assim as condições materiais de existência de grupos socioculturais territorialmente referenciados e destroem-se os direitos das populações que estão inseridas em formas sociais de produção nãocapitalistas (ACSELRAD, 2008, p. 6-7).

Nessa perspectiva de Ascelrad (2008), vê-se o movimento da acumulação capitalista expropriando a população camponesa dos seus territórios originários, e apropriando-se de forma perversa dos recursos da natureza. Essa pesquisa nos indicou que, mesmo quando esses empreendimentos capitalistas não conseguem expropriar as famílias camponesas da terra, engendram, pelo território das comunidades rurais, as consequências das suas formas predatórias de produção, ocasionando interferências danosas aos bens comuns desses camponeses.

Em nível local, o empreendimento capitalista do dendê age de forma direta e indireta na destruição da natureza, interferindo no ritmo de vida das populações camponesas e demais vidas silvestres que habitam o entorno da monocultura da palma.

Outro aspecto decorrente dessa apropriação desastrosa da natureza pelo capital é a intensificação do desmatamento e suas consequências.

\footnotetext{
${ }^{4}$ Entre os latinos americanos de língua espanhola, destacamos os trabalhos de Eduardo Gudynas, Maristella Svampa, Raúl Zibech, Alberto Acosta e Edgardo Lander. Entre os estudiosos brasileiros destacamos os trabalhos de Henri Acserald e Carlos Walter Porto-Gonçalves e, mais especificamente na Amazônia, de Violeta Refkalefsky Loureiro, Rosa Acevedo Marin, Edna Castro e Alfredo Wagner de Almeida.
}

Estudos Geográficos, Rio Claro, 17(1): 256-278, jan./jun. $2019 \quad$ (ISSN 1678-698X) http://www.periodicos.rc.biblioteca.unesp.br/index.php/estgeo 
Mudou muito, no início da implantação teve um grande desmatamento de áreas e a nossa agricultura foi prejudicada porque toda a fauna que antes vivia nessas áreas vieram acabar na nossa propriedade. Então a nossa produção, caju, goiaba, toda essa produção que a gente tinha em larga escala foi embora $50 \%$ mais ou menos, porque os pássaros, todos os bichos, raposas procuraram lugar pra comer né, e aí como a gente não podia matar, nem pela quantidade do que tinha, nem porque ninguém tinha a prática de ficar matando animais. Mas graças a Deus o dendê, ele cresceu e ele produz também o fruto né, e não é muito animais, mas pelo menos os que mais fazem concorrência, tatu, paca, esses bichos assim, eles voltaram para lá né. $\mathrm{E}$ a questão dos pássaros, nós convivemos com eles, não tem como não viver. Tu chega aqui de manhã, eles estão aí, mas aí pelo menos fica meia meia né. Mas de 2007 a 2010, tivemos uma perda de $50 \%$ da nossa produção, foi muito, agora não (J. P., Comunidade Nova Esperança, Concórdia do Pará, 14 de agosto de 2017).

Observa-se, a partir do enxerto acima, as consequências do desmatamento implementado pela Biopalma no contexto da implantação do Polo Concórdia. Mais uma vez, notamos que a apropriação capitalista do território insiste em afrontar as unidades camponesas, nesse caso, orquestrando uma disputa pela colheita das frutas entre os camponeses e a fauna que migra após a destruição de seu habitat natural pela empresa. A proliferação de insetos e mosquitos também tem sido um agravante em função das plantações de dendê, e nas falas dos camponeses evidencia-se como uma situação que se intensificou após a implantação da oleaginosa na região.

A pesquisa tem revelado que a interferência dos empreendimentos capitalistas extrapola o processo de expropriação causado com a mercantilização da terra para a implantação dos projetos do capital, gerando problemas para as comunidades ao entorno. Em campo, observamos que além da questão ambiental, após a expansão do dendê na região em estudo, houve aumento da violência e a precarização das estradas de acesso aos sítios familiares.

Por meio dos dados levantados nos territórios campesinos, evidenciamos a existência de relação de reciprocidade, pela qual o bem comum parte de uma valorização coletiva, mantendo as famílias unidas para a realização dos serviços que beneficiarão a todos. Nesse caso, a manutenção das estradas em boa situação é imprescindível para a realização do ir e vir com o externo da unidade doméstica. Ao mesmo tempo em que se evidencia uma solidariedade interna, se constata a total ausência do poder público atuando nas frentes que the cabe, a exemplo, da infraestrutura, em particular a melhoria e abertura de ramais e estradas.

O nosso problema aqui maior é da falta de estrutura por parte do município. Problema de ramais, atendimento de saúde de quando a gente precisa. A educação é muito falha e a segurança também, a gente fica aí com a segurança que Deus nos dá, infelizmente é isso (J. S., comunidade Conceição do Guajará, Bujaru, 12 de maio de 2016).

O problema maior aqui na comunidade é o ramal que tá nessa situação. Transporte escolar também é outro problema aí, passa semana que não vai e se queixa que é do ramal. Como a gente tem um posto de saúde ali no 29 , também é um outro problema porque lá

Estudos Geográficos, Rio Claro, 17(1): 256-278, jan./jun. 2019 (ISSN 1678-698X) http://www.periodicos.rc.biblioteca.unesp.br/index.php/estgeo 
não tem nada, só funcionário (J. C., comunidade Conceição do Guajará, Bujaru, 13 de maio de 2016).

Começa pela estrada, dificuldade devido a estrada. Isso aí é uma das principais dificuldades. Ultimamente a gente tem sofrido com a violência, essa violência relacionada a bandidagem né. $O$ aumento do consumo de droga tem a ver, porque a violência aumenta por causa da droga (C. C., comunidade Mariquita, Acará, 10 de setembro de 2016).

A dificuldade que nós temo aqui é a estrada, que nós não temo estrada. Vai lá com o prefeito, o prefeito diz que não vai mexer com isso, que não tem condição de mexer com isso agora, mas que pelo menos viesse jogar pedras, alguma coisa. A maior dificuldade nossa aí é isso aí pra gente viajar. Esse é o principal que afeta tudo é a estrada, é sobre saúde, é a educação (R. S., comunidade Mariquita, Acará, 04 de setembro de 2016).

As comunidades localizadas mais para o interior, em relação às rodovias, possuem vicinais de acesso em condições precárias, dificultando a mobilidade dessas famílias, fragilizando e mesmo impedindo a comercialização de sua produção, o trânsito até a escola, ao posto de saúde e à cidade, entre outras ações. As famílias das comunidades da Mariquita, Conceição do Guajará e Peixe são as que mais têm vivido esse transtorno, e mostram-se insatisfeitas com o ramal, o que tem dificultado a entrada de carros e ônibus nas localidades.

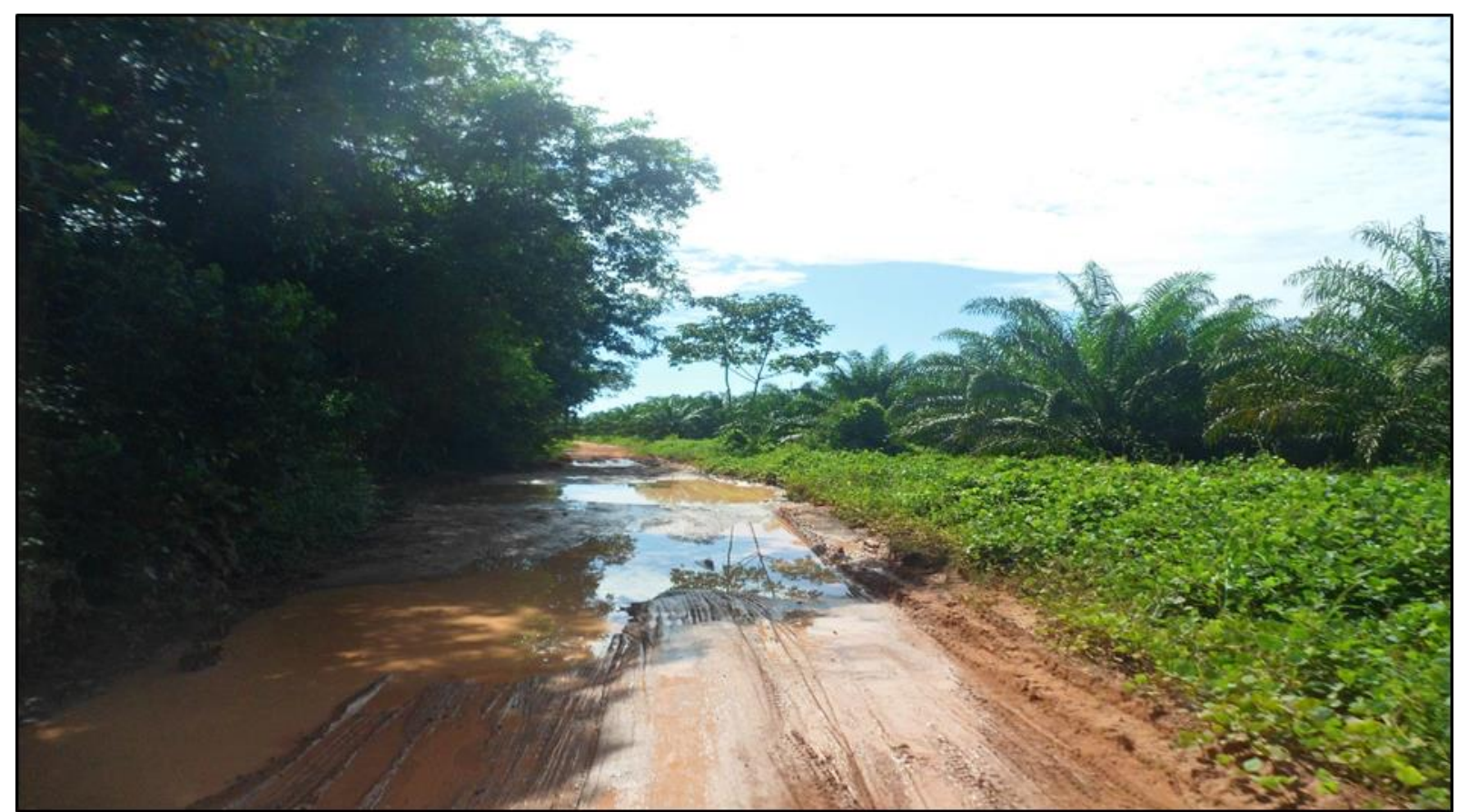

Fotografia 04 - Vicinal de acesso às comunidades de Conceição do Guajará (Bujaru) e Mariquita (Acará).

Fonte: Diário de campo, 2016.

Percorrendo as vicinais (a exemplo da fotografia 04), visualizamos a precariedade das estradas que dão acesso às comunidades. Depoentes vizinhos ao território da Biopalma relatam que a deterioração do ramal é causada pelo intenso tráfego de caminhões pesados transportando a oleaginosa.

Estudos Geográficos, Rio Claro, 17(1): 256-278, jan./jun. 2019 (ISSN 1678-698X) http://www.periodicos.rc.biblioteca.unesp.br/index.php/estgeo 
Um dos problemas causados pela Biopalma é devido o grande trafego de tratores, caminhões que bagunçam com as estradas. A quantidade e tamanho de buraco, cratera que fica quando eles passam e que fica na estrada. Eu não sei porque que o prefeito não vai com eles pra ajudar consertar. Que antes o ramal ficava feio, mas não assim. Tem dia que a gente encontra sete, oito tratores, um atrás do outro, já pensou, passar no mesmo tempo no ramal que já não tá bom (C. C., comunidade da Mariquita, Acará, 10 de setembro de 2016).

Esse dendê que veio pra nós aqui, foi só acabar com as estradas, foi só isso. Agora os vereadores fizeram uma reunião com o gerente deles lá, eles prometeram de ajudar, fazer parceria com o prefeito né. Agora no verão ajudar a fazer a estada, porque eles fizeram parte do desmantelo da estrada, eles fizeram parte, porque são carretas e carretas cheio de dendê né, com trator, esses veículos pesados, aí acabou com tudo. Com muita chuva, a terra vai cedendo, vai fundando, vai ficando esse lago aí, do jeito que tá aí. A gente vai de carro pequeno pra chegar na curva [Km 29] é sacrifício (R. S., Comunidade Mariquita, Acará, 04 de setembro de 2016).

Observamos que a presença da empresa na dinâmica do território não reflete em melhoria de vida dessa população, pelo contrário, a presença da empresa tem intensificado os problemas de mobilidade de acesso à PA140. Como veremos mais adiante neste trabalho, a territorialização do dendê por entre as comunidades em pesquisa não tem alcançado a tríade do desenvolvimento sustentável que é apregoado ao empreendimento da palma de óleo no Estado, a saber: a equidade ambiental-social-econômica.

Por entre as comunidades, é possível perceber uma pressão oriunda de grandes empreendimentos capitalistas sobre o território camponês, seja pela venda da terra, seja pela integração, seja pelo trabalho assalariado. Fora esses aspectos, também podemos perceber a ausência de projetos compensatórios e de investimento em projetos sociais que amenizem as dificuldades de viver no campo.

Em relação às vicinais, no período da pesquisa, percebemos que, enquanto ocorre a precarização dos ramais de acesso às unidades domésticas, os varadouros das empresas vêm preservando-se em perfeito estado, ganhado manutenção periódica. O mesmo não ocorre com as estradas usadas pelas famílias camponesas que, por terem que enfrentar a falta de compensação das empresas e a ausência da prefeitura municipal, organizam-se em mutirão para a manutenção do ramal e, assim, conseguem manter o direito de ir e vir.

Outra dificuldade relatada pelas famílias está relacionada à falta de energia elétrica, que ainda não chegou em todas as residências ou existe de forma ineficiente.

Até hoje não tem luz aqui, já fiz tanto pedido. Isso aí eu já dei por perdido. Já fizeram umas cinco cartas pra cá dizendo que vem, já implorei, já implorei e nisso já me incomodei, que não vem de jeito nenhum energia pra cá. E eu tenho necessidade que esse filho que é portador, ele tem necessidade, ele é uma pessoa retraída, então se tivesse uma televisão pra ele se interter. Se fosse pra eu cobrar pela justiça, isso era uma coisa que eu conseguiria, porque ele tem esse direito. Que foi feito o tratamento dele, aí foi jogado pela justiça pra liberara o benefício dele, quer dizer que eles deram todo esse direito

Estudos Geográficos, Rio Claro, 17(1): 256-278, jan./jun. 2019 (ISSN 1678-698X) http://www.periodicos.rc.biblioteca.unesp.br/index.php/estgeo 
pra ele, pela juíza né, a juíza deu todos os direitos, mas até hoje não veio e não vou lutar pela justiça porque a justiça demora muito. É capaz que eu morra e não consigo. Não sei não, porque a justiça ela é lenta, ela custa muito. Então eu não vou, eu vou esperar que Deus, tenho fé em Deus que um dia vem, nem que seja no dia em que eu já tiver quase indo desse mundo, que meus filhos, netos cheguem a conclusão de ter a energia nas barraquinhas deles (M. B., Comunidade Conceição do Guajará, Bujaru).

A família de M. B. faz parte das unidades domésticas que ainda esperam pela eletricidade. Distante da vicinal de acesso à comunidade de Conceição do Guajará, o local de morada dessa família fica distante dos postes de transmissão de energia, o que dificulta a conexão com a rede elétrica.

Até o fechamento dessa pesquisa, na comunidade do Peixe, no município de Acará, as famílias continuavam sem acesso à eletricidade, e os linhões de transmissão de energia estavam a três quilômetros do centro da comunidade. Essas famílias vivem na contradição do desenvolvimento imposto pelo agronegócio do dendê, enquanto estão cercados por uma agricultura voltada à produção de combustíveis renováveis, continuam vivendo à energia movida por combustíveis fósseis. Percebemos que continuar na comunidade tem sido um desafio ao longo do tempo, para o qual a luz da lamparina torna-se uma companheira fiel na insistência em viver no campo.

Além das famílias que não têm acesso à eletricidade, existem outras que buscam mecanismos na clandestinidade para ter luz em casa. Em um relato feito por uma moradora da comunidade do $\mathrm{Km}$ 29, a entrevistada confidenciou que: "a dificuldade pra nós aqui é a energia elétrica né. Aqui tudo é gato, aí se um dia resolverem cortar, aí já viu né a dificuldade" (comunidade Km 29, Bujaru, 18 de março de 2017). Na comunidade do $\mathrm{Km} \mathrm{29}$, formou-se uma vila de casas paralelas à PA140, que, sem infraestrutura adequada e omissão do poder público, conectou-se à rede de eletricidade de forma ilegal.

Outro ponto observado em campo, também em relação à energia elétrica, é a baixa intensidade dos volts da eletricidade que não dão o suporte necessário para a quantidade de equipamentos nas residências.

Nós temos problemas com a rede elétrica porque a energia aqui é de baixa qualidade. Porque quando colocaram, que ninguém tinha seus eletrodomésticos, as suas coisas, dava tranquilo. Mas a partir do momento que começou, que foi evoluindo, todo mundo comprando geladeira, televisor, seu freezer, ventilador, micro-ondas, aí pronto, a energia que foi colocado pra época, agora não é suficiente (J. P., Comunidade Nova Esperança, Concórdia do Pará, 14 de agosto de 2017).

Com essa fala, observamos a necessidade de eletricidade de boa qualidade no campo frente à diversidade de equipamentos eletrônicos encontrados nas unidades familiares. Com a presença da energia elétrica há um maior dinamismo no núcleo familiar camponês, que diversifica a possibilidade de consumo e faz melhor aproveitamento de frutos que antes se estragavam pelo quintal.

Com a energia mudou muita coisa né. Fruta que a gente não vencia, por exemplo, o muruci a gente não vencia, pra beber suco todo dia a gente não vencia. Agora vence porque a gente ajunta, faz a polpa,

Estudos Geográficos, Rio Claro, 17(1): 256-278, jan./jun. 2019 (ISSN 1678-698X) http://www.periodicos.rc.biblioteca.unesp.br/index.php/estgeo 
vende a polpa né. Cupuaçu estragava muito, agora não vai mais, graças a Deus. Antigamente você só comia comida todo tempo era salgada, se você comprava uma carne tinha que salgar né. Se você comprava peixe fresco você tinha que salgar né. Agora não, você come fresco. Então melhorou muito, a gente já assiste coisa de Brasília que antes a gente não assistia né, que não sabia e agora tá por dentro dessas questões. Então melhorou bastante (I. S., comunidade de Castanhalzinho, Concórdia do Pará, 22 de janeiro de 2017).

Observamos no depoimento de I. S. a mudança que ocorreu com a chegada da eletricidade na comunidade de Castanhalzinho, principalmente no hábito alimentar e na possibilidade de outras formas de comercialização, como a venda de polpas de frutas. De certa maneira, com a presença da energia elétrica, outras situações de conforto tornam-se possíveis, como a água encanada de poços artesianos, redes de telefones móveis, processamento das frutas dos quintais, instalações sanitárias adequadas, entre outros bens comuns que ajustam melhores condições de vida no campo.

Durante a pesquisa, enquanto encontramos famílias que se adequam aos direitos de consumo proporcionados pela chegada da eletricidade e os assimilam, percebemos também que ainda persistem famílias que abrigam no seu cotidiano antigos costumes e tradições de vida.

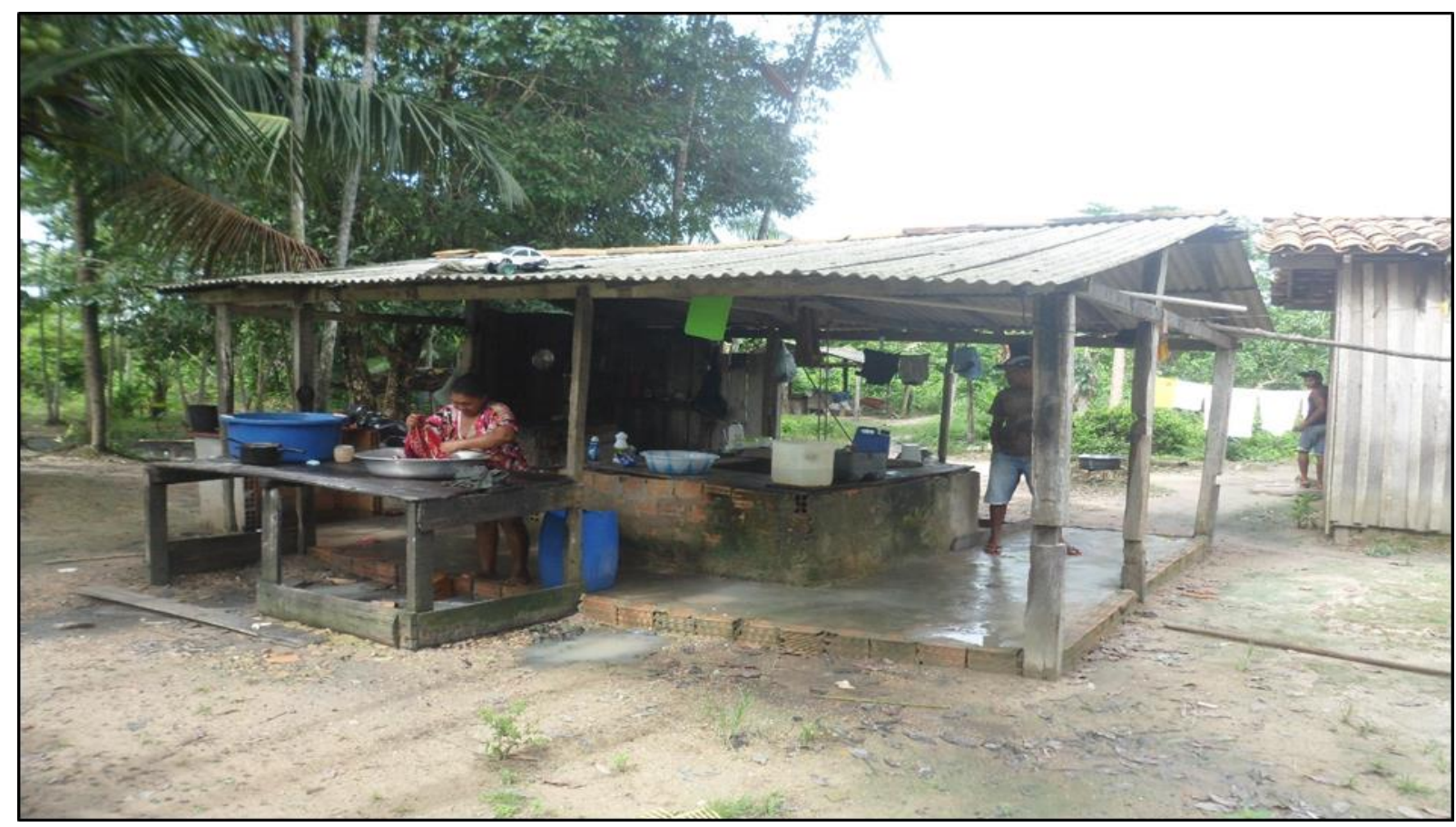

Fotografia 05 - Cozinha externada a casa.

Fonte: Diário de campo, 2017.

$\mathrm{Na}$ fotografia 05, observamos uma cozinha externa à residência, ainda mantendo a estrutura e o uso dos poços amazônicos para os serviços domésticos. A utilização desse poço, ainda manuseado pela força humana, é a alternativa dessa família para captar água, devido à ausência de sistema de distribuição de água encanada na comunidade e à falta de recursos econômicos da família para a construção de uma rede de saneamento particular.

Estudos Geográficos, Rio Claro, 17(1): 256-278, jan./jun. 2019 (ISSN 1678-698X) http://www.periodicos.rc.biblioteca.unesp.br/index.php/estgeo 
Compreendemos, a partir da pesquisa, a existência de uma diferença social entre as famílias camponesas, algumas inseridas de forma mais acintosa ao acesso a bens de consumo, e as que ainda mantêm formas antigas de uso do bem comum. Os aspectos sociais observados nas comunidades pesquisadas demonstram que não há nenhuma intervenção do agronegócio do dendê na melhoria das condições de vida no campo. A ausência, ou a pouca presença, do Estado também tem sido sentida pela precariedade dos ramais, do transporte escolar e dos serviços de saúde que não são suficientes para atender à demanda da população.

Com isso, entende-se que por entre o desenvolvimento dos grandes projetos na Amazônia há a conformação de espaços de pobreza como resultado da concentração de riqueza reproduzida sobre a exploração da natureza, deixando na circunferência dos empreendimentos os problemas sociais, a expropriação e a violência.

Esses novos capitais conferiram ao modelo exportador de produtos semi-elaborados ou in natura um novo impulso e dinamismo, sem alterar suas características históricas básicas: a) a excludência social, já que as camadas pobres e os moradores naturais ficaram de fora dos benefícios concedido aos investidores; b) pouca diversificação das atividades econômicas e dos processos produtivos, uma vez que os produtos incentivados - madeira, gado, etc. -, tal como no passado distante (com raras exceções) continuam sendo pouco industrializados, o que resulta numa reduzida divisão do trabalho e numa baixa geração de emprego; c) concentração de renda, devido às mesmas razões (LOUREIRO, 2009, p. 43).

A reprodução ampliada de capital na Amazônia tem conferido para a região aumento da expropriação camponesa diante da precarização da vida no campo, exclusão historicamente construída e perpetuada pela conformação territorial do capital.

A produção incessante da exclusão e da desigualdade social é inaceitável por várias razões. Em primeiro lugar, porque ambas incidem sobre as camadas sociais que já são mais desprotegidas, evidenciando um aspecto vergonhoso da história contemporânea do Brasil e da região. [...]. Em segundo lugar, a desigualdade e exclusão social são inaceitáveis, também, pelo fato de que a ideologia do progresso, da modernidade e da própria filosofia liberal, acenou com a perspectiva de liberdade, de cidadania e de bem-estar para todos e não apenas para os cidadãos dos países centrais e elites dos países periféricos (LOUREIRO, 2009, p. 43-44).

Observamos, desse modo, que o desenvolvimento territorial da agricultura capitalista, a exemplo do agronegócio do dendê, não se envolve com as comunidades ao entorno do empreendimento. A inclusão camponesa nesse processo tem sido desencadeada por meio da exclusão, da subalternização, da exploração do trabalho e da expropriação da terra. Isso demonstra a contradição do projeto do óleo de palma no estado do Pará, que produziu um slogan de combate à pobreza e ao desmatamento.

A trajetória de vida do campesinato e das comunidades em estudo aponta para a existência de estratégias de sobrevivência e mecanismos de reprodução

Estudos Geográficos, Rio Claro, 17(1): 256-278, jan./jun. $2019 \quad$ (ISSN 1678-698X) http://www.periodicos.rc.biblioteca.unesp.br/index.php/estgeo 
social pautados na luta pela terra e no direito de permanecer nela, apesar da precarização e da exclusão social em que essas comunidades estão inseridas.

\section{ALGUMAS PALAVRAS FINAIS}

Inferimos, assim, que as empresas do agronegócio do dendê não engendram modificações apenas na sua propriedade, mas a partir de sua racionalidade produtiva, ocasionam problemas para as populações do entorno, interferindo direta e indiretamente nas relações de trabalho e de vida que podem comprometer a reprodução social dessas famílias.

A implantação do Polo Dendê de Concórdia, da Biopalma, foi acompanhado por um movimento de r-existência mobilizado pelo sindicato dos trabalhadores rurais (STR) e pelas associações quilombolas que não "viam" com bons olhos a implantação do projeto da palma na região.

Além do agrocombustível do dendê não ter conseguido fazer chegar suas supostas benesses aos camponeses do nordeste paraense, essa atividade intensificou problemas antigos e gerou novos. As dificuldades de mobilidade das populações que vivem nessas comunidades agravaram-se com a abertura de ramais para o transporte dos cachos de dendê que, por se tratarem de carros pesados, torna quase que intrafegável as vias para carros pequenos, pedestres, bicicletas e motos. Além disso, não foram criadas políticas compensatórias que mitigassem velhos e novos problemas.

Apesar do cercamento que a expansão do dendê engendrou sobre essas comunidades camponesas, observamos camponeses que resistem e que lutam, organizando estratégias para continuar a morar no campo, vivendo da roça, criando e recriando mecanismos que se materializam na territorialidade desses camponeses no espaço agrário do nordeste paraense.

Assim, a implantação e a expansão da palma do dendê no nordeste paraense insere-se na região como mais uma estratégia de avanço acelerado do capital, impondo aos povos do campo uma ação devastadora, tanto aos seus territórios quanto aos seus modos de vida. Mais do que nunca é sentida a tentativa de apropriação do bem comum, alijando-os do uso comunitário e/ou coletivo desses bens. A disposição do território da palma na área de estudo anuncia a continuidade da acumulação via espoliação.

\section{REFERÊNCIAS}

\section{ACSELRAD, H. Sustentabilidade e articulação territorial do desenvolvimento} brasileiro. Anais: II Seminário Internacional sobre Desenvolvimento regional, Programa de Pós-graduação em Desenvolvimento Regional. Santa Cruz do Sul, RS, Brasil, 2008.

CANUTO, A.; MALVEZZI, R. Conflitos e violência: quando o econômico monopoliza o valor da água. In: CANUTO, A. et. Al. (ORGs.). Conflitos no Campo Brasil 2010/ CPT. Goiânia: CPT, 2011, p. 17-20.

Estudos Geográficos, Rio Claro, 17(1): 256-278, jan./jun. 2019 (ISSN 1678-698X) http://www.periodicos.rc.biblioteca.unesp.br/index.php/estgeo 
COSME, C.M. Crítica à transformação capitalista da água em mercadoria: águas para a vida, não para a morte. In: CANUTO, A. et. al (ORGs.). Conflitos no Campo - Brasil 2016. Goiânia: CPT Nacional - Brasil, 2016, p. 120-131.

FABRINI, J.E. $O$ campesinato frente à expansão do agronegócio e do agrocombutísvel. In: SAQUET, M. A. \& SANTOS, R. A. (ORGs.) Geografia Agrária, território e desenvolvimento. São Paulo: Expressão Popular, 2010.

GOMES, D.L. et al. Expansão territorial do dendê e resistência camponesa no Nordeste paraense. Caminhos de Geografia (UFU), v. 17, 2016, p. 191-200.

MACEDO, C.O.; SOUSA, R. B. Novos projetos, velhas práticas: os impasses entre agricultura camponesa e agronegócio do dendê em terras amazônicas. In: MACEDO, C. O. et. al (Orgs). Os "nós" da questão agrária na Amazônia. Belém: Editora Açaí, 2016.

MCMICHAEL, P. Regimes alimentares e questões agrárias. São Paulo; Porto Alegre: Editora Unesp; Editora da UFRGS, 2016.

NAHUM, J.S.; BASTOS, C.S. Dendêicultura e descampesinização na Amazônia paraense. In: NAHUM, J. S. (Org.). Dendêicultura e dinâmicas territoriais do espaço agrário na Amazônia paraense. Belém: GAPTA/UFPA, 2014.

Do sítio camponês ao lote de dendê: transformações do espaço rural na Amazônia paraense no século XXI. Revista NERA (UNESP), v. 37, 2017, p. 5476.

SOUSA, R. B. Pelas margens do Igarapé Arapiranga: o processo de territorialização camponesa no Município de Concórdia do Pará. UFF/PPGEO. Niterói: 2014. (Dissertação de mestrado) 